\title{
Learning to See Double
}

\author{
Brian L Ackerman MD $^{1 *}$ and Warwick RI ${ }^{2}$ \\ ${ }^{1}$ Staff Psychiatrist and Director of Meditation \& Mindfulness Services \& Training at the Kent Center, USA \\ ${ }^{2}$ Staff Psychiatrist at the Community Care Alliance in Woonsocket, USA
}

Submission: February 02, 2018; Published: February 12, 2018

*Corresponding author: Brian L Ackerman MD, Staff Psychiatrist and Director of Meditation \& Mindfulness Services \& Training at the Kent Center, USA, Email: ackermanpsychiatry@gmail.com

\section{Short Communication}

There are 2 fundamentally different and opposing parts of our psyches, one of which is healthy, the other is unhealthy. In order to become mentally and spiritually well, we have to become aware of our 'double nature', which I refer to as learning to see double, and then create a hierarchy between the two sides, such that our unhealthy psyches are relegated to a one-down, subservient position to our healthy psyches. Our unhealthy psyche goes by various aliases: ego, neurotic ego, monkey brain, mind, false self. It is the home to all our worst thoughts, feelings, impulses, attitudes and behaviors. It is the home to our boredom, depression, anger, anxiety, fears, insecurities, and dread. It is the home of our negative thoughts, feelings, attitudes and our sense of defectiveness, deficiency and impaired self worth. It is the home for our irritability, impatience, criticalness, and of our being judgmental. It is the home to our comparative thinking where we quickly compare ourselves to others and alternatively feel inferior or superior. It is the home to our capacity for guilt, shame, self-hatred, for feeling wronged and victimized. It is the home to our capacity to act like we don't care. It is the home to our impulsivity and our capacity to self-sabotage. It is the home to our temper, our rage, aggression, and vulnerability to

becoming violent. It is the home to our indifference. It is the home of our foolishness, stupidities, and our unwise decisions. It is the home of our vanity, our superficiality, our phoniness, our willingness to lie, to deceive, and to exploit others.

It is the home of our neediness, dependency, and our robust capacity to complain.. It is the home to our tendencies to blame others when things go wrong. It is the home to our ability to see the same faults in others that we can't see in ourselves. It is the home to our defensiveness and how easily our backs arch when someone points out something about us that Is unflattering. It is the home of our wishful thinking, our illusions, and our recalcitrant desire for things to be different then they are. It is the home to our obsessive thinking, our money preoccupations, our selfishness, our greed, and our worries about our status.
It is the home of our negative self-talk. It is the home of our reactivity, our resentment, and our bitterness. It is the home to our alienation and estrangement. It is important to make particular note of just how many different features there are of our unhealthy psyche. There is not just one color of black; there are over 50 shades of gray. There is a lot of seaweed we have to wade through to get to the crystal clear ocean beyond.

Our healthy psyche, AKA, our heart, soul, and spirit is the home of our positive self-regard, our sense of value and worth, our positive thoughts and positive feelings, our sense of capability, confidence, optimism, hope, our compassion, love, gratitude, thoughtfulness, kindness, considerateness, forgiveness, laughter, humor, creativity, spontaneity. It is the home to our curiosity, and our openness and willingness to learn. It is the home to our intelligence and our ability to use our intelligence to problem solve. It is the home of our capacity to become a non-judgmental, compassionate witness to ourselves. It is the home to our capacity for fun, enjoyment, and true well being. It is the home to our capacity for play, for enjoying listening to and playing music, for dance, song and celebration. It is the home to our resiliency and our capacity to grow and change. It is the home to our determination to realize our best selves. It is the home of our capacity to accept ourselves and others as being imperfect people. It is the home of our capacity to truly learn to care for ourselves and others. It is the home of our wisdom, our well-being, and healthy decision making. It is the home of our capacity to let go of the past, and to become aware of and free ourselves from the myriad of pre-occupations that sap our energy and attention. It is the home of our capacity to take moment by moment responsibility, to become aware of (mindful) of where we are at psychologically at every moment in time, and if we don't like where we are sitting to get up and change our seats.

It is the home of our capacity to distinguish our unhealthy selves from out healthy selves and become aware of all identifications we have made with our unhealthy psyches and 
free ourselves from these identifications. It is the home of our capacity to distinguish false, self-created 'cravings' from our truest desires and cravings for both physical and mental health. It is the home of our desire and capacity to take good care of ourselves physically, mentally, and spiritually. It is the home of our capacity for joy and inner peace. It is the home to our genuine self-regard, our capacity to be truthful, authentic and trustworthy. It is the home of our awe, wonder and curiosity. It is the home of our abilities to not only be more realistic but, to at least accept, if not embrace, that which is real. It is the home of our positive inner talk and of our ability to not take things personally. Our healthy psyche is also power packed, with so many different.

Dimensions to our healthy nature are our love, compassion, gratitude, playfulness, creativity, humor, which often combine in unique ways. It is like a Baskin Robbins with more 51 delicious flavors. When you step back and look objectively at both the unhealthy and healthy psyches you will see just how jam-packed each is with its respective features. If you can imagine that at one point the unhealthy psyche was just like an empty vase and then it started to get filled up with mild negative feelings like boredom, disappointment, irritation and anxiety, and then some spicier ones were added like rage, resentment, bitterness, vindictiveness. Then they packed in some mild negative thoughts like suspiciousness, thinking others dislike you, negative anticipations and then some really spicy negative thinking like 'I 'm worthless', 'I hate myself', 'I'm disgusting'. And to top it off, they packed in rather intense self-harming, self-sabotaging impulses coupled with an uncanny ability to rationalize these behaviors. Given that these two rather dramatically opposing parts of our psyche are built-in and packed into the brim, it can start to become apparent to us how crucial it becomes to become aware of our doubleness. Learning to see double is what every trained firefighter does when he enters a fire. He keeps one eye on the smoke, the other eye on the fire. He knows you can't have one without the other. He knows the smoke can cause so much damage and discomfort he may never reach the fire unless he has learned to protect himself from the smoke. When we train in mindfulness we train to become aware to the toxic smoke of our unhealthy psyches, and never confuse with the smoke with true fire of our inner natures and burning desires to live happily, joyously and smoke free. When we adopt a holistic view of ourselves we learn to hold all these pieces-the unhealthy and the healthy ones-in our arms with great love and compassion. When we do so, the unhealthy pieces are acknowledged without being encouraged or indulged, therefore limiting the degree to which they are allowed to distract and disturb our inner peace which is the natural state of our healthy psyche. Our inner peace is ours for the taking if we can just persuade our unhealthy psyches to just quiet down a bit as in the Isley Brothers lyric "A little bit softer now". From a holistic point of view, we are also striving to accept our different psyches and whenever possible get them to work with one another not just against one another.
One example is the story of the two persons who were trapped in a house fire, one who was blind but physically fit; the other who was paralyzed at the waist, but could see. At first, they each became quite apprehensive as to how each would survive. But they brainstormed it, and focused on each of their abilities and solved the problem: the blind fit man carried the paralyzed man who in turn could directed the blind man where to go to reach safety. Most of the time we are striving to get our healthier, clearer seeing, psyche to be in charge of our more disabled and blinded unhealthy psyche. It is the healthy psyche that we want to be in charge, just as we would want a competent and mature baby sitter to be in charge of our children if we left them in their care. One of the purposes of mindfulness is to establish a healthy hierarchy and establish a leadership role for the healthy psyche. We are not born with this healthy hierarchy already established. But we are born with the capacity to recognize that that this hierarchy needs to be established, learn that we are capable of establishing it, and recognize that no-one can do this for us; we have to do it for ourselves. There is nothing more disabling for human beings than having a disabling psyche which is not acknowledged. While nobody can run the marathon for us, and nobody can acknowledge our disabling psyche for us, there are many people rooting for us and cheering us on. In time, we will be rooting for and cheering on others as well. Beyond our disabling psyches are our able psyches. Getting our able psyches up and running the show is our greater mission.

One can wonder why we were not born with this healthy hierarchy already established for us. Or perhaps we could just appreciate that at least we were born with the capacity to recognize our duality and the fix we are in,, and learn to evolve and complete our own development. Our unhealthy psyches function like inner and invisible wounds. To get well, we must heal these wounds. We need to take the proverbial bull by the horns, become pro-active and ongoing witnesses to the ongoing tug of war between our dueling psyches, and then choose which side were are going to fund, support, and strengthen. We also need to remember that all human beings have similar struggles with their duality. Learning to see ourselves and others with this double vision is at the heart of mindfulness and gives us a framework which can help us to understand ourselves better. It also guides us to see what we need to change in.

Our inner lives that will enable our outer lives to become better. We don't want to put a Band-Aid on our skin when our wounds are deep inside. We know that all healthy healing happens from the inside out. With mindfulness we learn how to utilize the healing powers of the healthy psyche to soothe and heal the wounds of the unhealthy psyche. We learn to acknowledge and tend to our unhealthy wounded psyches without letting them govern us. This in turn leaves us freer to live our lives governed by our truest inner nature which by its very nature is peaceful and joyous. 
This work is licensed under Creative Commons Attribution 4.0 License

DOI: 10.19080/PBSIJ.2018.08.555742

\section{Your next submission with Juniper Publishers} will reach you the below assets

- Quality Editorial service

- Swift Peer Review

- Reprints availability

- E-prints Service

- Manuscript Podcast for convenient understanding

- Global attainment for your research

- Manuscript accessibility in different formats ( Pdf, E-pub, Full Text, Audio)

- Unceasing customer service

Track the below URL for one-step submission https://juniperpublishers.com/online-submission.php 